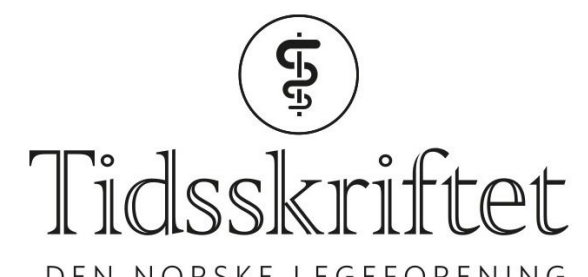

DEN NORSKE LEGEFORENING

\title{
Grundig og nyttig om kompleksbinding av metaller
}

ANMELDELSER

JAN ALEXANDER

Fagdirektør, Folkehelseinstituttet

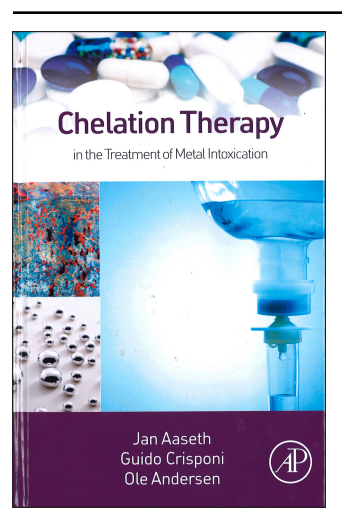

Jan Aaseth, Guido Crisponi, Ole Andersen

Chelation therapy in the treatment of metal intoxication

371s, tab, ill. London: Academic Press (Elsevier), 2016. Pris USD 150

ISBN 978-0-12-803072-1

Dette er en stor og velskrevet bok om et tema som vanligvis ikke vies særlig oppmerksomhet.

Den gir en grundig innføring i agens som kompleksbinder metaller - kelatorer. Disse brukes ved intoksikasjoner med metaller eller ved tilstander der metaller avleires. Forfatterne sier at boken kan være nyttig for klinikere som behandler slike tilstander. Den kan også være nyttig for spesialister i medisinsk biokjemi, forskere innen metalltoksikologi og forskere som arbeider med sykdomstilstander der dysregulering av metallomsetningen er av patogenetisk betydning.

Studier av kelatorer går tilbake til 1940-årene da stoffet BAL (British Anti Lewisite/2,3dimerkaptopropanol) ble utviklet som en antidot mot den arsenholdig krigsgassen lewisite (diklor-2-klorvinylarsin). Senere ble BAL anbefalt ved kvikksølv-, bly- og kobberintoksikasjon. Desferal er i bruk mot jernforgiftning og ved jernavleiring ved sigdcelleanemi og talassemi. Denne jernkelatoren har reddet livet til mange barn med jernforgiftning og hundre tusener med disse blodsykdommene.

Vi får en grundig innføring i basale prinsipper for terapeutisk bruk av kelatorer og kjemiske 
egenskaper til de mest aktuelle kelatorene. Metaller kan være både essensielle og ikkeessensielle. De essensielle metallene er bl.a. viktige kofaktorer i enzymer som katalyserer reduksjoner og oksidasjoner, men kan være skadelige i høye mengder. Toksiske metaller som kadmium kan gå inn på sinks plass. Kelatorbehandling tar sikte på å rive løs avleirede essensielle metaller og toksiske metaller fra bindingsseter og gjøre dem utskillbare i urin.

Leseren får en omfattende oversikt over kliniske og eksperimentelle studier av behandling med kelatorer ved metallforgiftninger og fjerning av radioaktive metaller fra kroppen.

Kliniske aspekter ved kelatorbehandling av sykdommer som innebærer lagring av metaller og enkelte nevrodegenerative sykdommer der dysregulering av metallomsetning kan ha en patogenetisk betydning, diskuteres.

Forfatterne tar ikke opp misbruk av keleringsterapi ved tilstander der effekt ikke er dokumentert, som f.eks. kelering av kalsium ved arteriosklerose og tungmetaller ved tilstander der det ikke foreligger en dokumentert intoksikasjon.

Nye, mer effektive kompleksbindere er dessverre i mindre grad testet ut i kliniske studier. For noen bruksområder er det liten økonomisk gevinst ved klinisk uttesting, mens for sykdommer som rammer mange, f.eks. talassemi, er situasjonen bedre.

Publisert:30. oktober 2018. Tidsskr Nor Legeforen. DOI: 10.4045/tidsskr.18.0596

(C) Tidsskrift for Den norske legeforening 2020. Lastet ned fra tidsskriftet.no 